\title{
Skolegymnastikkens modernisering 1884-1913
}

\author{
af Søren Copsø
}

Omkring århundredeskiftet gennemgik den danske skolegymnastik en mere vidtrækkende reformering. Tidligere havde ansvaret for såvel den civile gymnastiklæreruddannelse som fagets undervisningsindhold været lagt $\mathrm{i}$ hænderne på medarbejdere ansat ved Hærens Gymnastikskole under Krigsministeriet; for fremtiden skulle disse aspekter nu varetages af skolens eget ministerium - Kultusministeriet. I 1898 markerede dette ministerium sin debut som eneansvarlig for fagets udvikling med oprettelsen af en civil gymnastiklæreruddannelse. Og året efter fulgtes reformbestræbelserne op med udsendelsen af gymnastikhåndbogen af 1899 , der ved hjælp af såvel et nyt undervisningsindhold som en ændret fagpædagogisk holdning forsøgte at bibringe skolegymnastikken en mere tidssvarende profil.

Disse landvindinger, der ikke blev nået uden sværdslag, var et resultat af knapt 20 års bestræbelser udfoldet af personer med nær tilknytning til hovedstadens skolepædagogiske miljø. Og hensigten med denne artikel er dels at skitsere nogle af udviklingens hovedpunkter dels at vurdere reformerne i sammenhæng med, hvad der ellers skete på skoleområdet i disse år.

\section{Lidt om idé og baggrund}

Da jeg i 1982 havde nået det punkt i mit historiestudium, hvor jeg skulle vælge specialeemne, udkom Ove Korsgards bog ",Kampen om kroppen“. Med den som inspirationskilde tillige med et undervisningsforløb over temaet sportshistorie og sportsteori gav jeg mig i kast med et speciale inden for det forholdsvis nye forskningsfelt - idrætshistorie. Emnet blev den danske skolegymnastiks udvikling 1884-1913; og opgaven, der udgør artiklens fundament, blev afleveret i efteråret 1983, samtidig med at jeg startede på idrætsstudiet ved Odense Universitet.

Et af de spørgsmål jeg ønskede belyst var, i hvilken udstrækning det politiske systemskifte i 1901 spillede en rolle for reformeringen af landets skolegymnastik, samt endvidere hvor tidligt landets gymnastiklærere var i stand til at formidle de nye tanker. Hidtil har det været fremført, at Venstres 
regeringsovertagelse i 1901 sikrede indførelsen af svensk gymnastik i de danske skoler. Når man er nået frem til denne antagelse, hænger det sammen med, at de Venstre-orienterede højskoler siden midten af 1880'erne havde taget denne gymnastikform til sig og i kampen for dens udbredelse var kommet op at toppes med tilhængerne af den praktiserede danske gymnastik. Konfrontationerne mellem fortalerne for de 2 forskellige gymnastikopfattelser var meget indædte i midten af 1880'erne, men nogen nærmere præcisering af gymnastikdebattens start og slutning har ikke tidligere været foretaget. Derfor har det for eftertiden taget sig ud som om striden stod på frem til årene omkring århundredeskiftet. På det tidspunkt udsendte ministeriet en tvedelt gymnastikbog, der dels bestod af et modificeret svensk gymnastiksystem dels af et afsnit omhandlende boldspil og anden idræt. Gymnastik og boldspil blev på daværende tidspunkt betragtet som 2 konkurrerende idrætsformer. Da ministeriet senere udsendte et par cirkulærer, som tilsyneladende indskrænkede boldspillenes anvendelse i skolegymnastikken, kunne det umiddelbart give det indtryk, at højskolefolkene havde trukket det længste strå i striden om skolegymnastikkens udformning. Og det har været nærliggende at se denne udvikling i sammenhæng med Venstres stigende indflydelse omkring århundredeskiftet på såvel ministeriel som regeringsplan. De grundtvigsk-orienterede højskoler havde tradition for udveksling af synspunkter med Venstre-kredsene.

For at afdække udviklingen bag skolegymnastikkens modernisering var det nødvendigt at gå tilbage til midten af 1880'erne og underkaste gymnastikdebatten en nærmere analyse. Hvad forårsagede den og hvor lang tid stod den på? Hvem var aktive og hvilke synspunkter fremførte de? Og endelig: hvilke konsekvenser fik debatten for skolegymnastikkens udvikling? Kun ved besvarelse af disse spørgsmål var det muligt at bedømme, om fagets forandring havde noget at gøre med Venstres styrkede position.

Et andet væsentligt punkt $\mathrm{i}$ emnets behandling var fremskaffelsen af relevant materiale. Da idrætshistorie som forskningsfelt er af nyere dato var denne proces til tider besværlig og langsommelig. Specielt fordi den eksisterende litteratur som hovedregel ikke har støttet sig til akter og andet arkivalsk materiale. Måske ud fra en forestilling om, at dette materiale ikke fandtes. Det gør det imidlertid; og endda i rigt mål. Men spredt over det ganske land. På Rigsarkivet fandt jeg brugbart materiale fra Kirke- og Undervisningsministeriets arkiv, fra Gymnastikinspektionens arkiv, fra embedsarkiver, fra privatarkiver. Og uden for Rigsarkivet har jeg været på strandhugst i Ordenskapitlet, på Landsarkiverne i Lund og Odense, på Danmarks Højskole for Legemsøvelser, på Danmarks Pædagogiske Bibl., på Danmarks Lærerhøjskoles Bibl. Endelig fik jeg materiale fra private. Uden 
inddragelse af disse arkivalier havde det ikke været muligt at afdække ovennævnte aspekter af idrætshistorien.

\section{Udgangspunktet - Fagets tilstand i midten af 1880'erne}

I midten af 80'erne var skolens gymnastikundervisning på flere måder ude af trit med den europæiske udvikling. Og det til trods for at landet med gymnastikkens indførelse som obligatorisk drengefag i 1814 havde markeret sig som en foregangsnation på området. Denne iøjnefaldende tilbagegang havde flere årsager.

Den gymnastikform, der i begyndelsen af 1800-tallet fik fodfæste her i landet, var inspireret af menneskets naturlige bevægelsesmønster. Det drejede sig om øvelser i spring, klatring, løb og svømning samt enkelte militære færdigheder. Der var således i overvejende grad tale om et pædagogisk gymnastikindhold, hvor formålet var at tilgodese ungdommens naturlige evne til at bevæge sig. Derfor havde man også oprettet en civil læreanstalt til uddannelse af skolens gymnastiklærere. I 1816 var statens kasse imidlertid tom, så læreanstalten måtte lukkes, hvorefter det Militære Gymnastikinstitut blev ene om at varetage skolegymnastikkens forhold. Det gjaldt både fagets indhold og læreruddannelsen. Denne udvikling medførte en gradvis drejning af undervisningen bort fra det pædagogiske udgangspunkt; de militære øvelser blev forøget i antal; og skolegymnastikken reduceret til en ,forskole for hæren".

I 1883 forsøgte den daværende chef for det Militære Gymnastikinstitut, Julius Amsinck, at ændre denne udvikling og gøre skolegymnastikken mere interessant og tillokkende for eleverne. Han udvidede øvelsesforrådet ganske betydeligt ved at introducere redskaberne barre, trapez og ringe. Hver især karakteriseret som enkeltmandsredskaber, der stillede store krav til elevernes forkundskaber. Og uanset at dette fra Amsincks side sikkert var et velment forsøg på at tilføre faget nye impulser, betød de forøgede krav blot, at endnu færre fik noget ud af gymnastiktimerne. Den danske gymnastik havde gennemgået en udvikling, der i stigende grad tog hensyn til eliten, så tilegnelsen af færdigheder blev fagets egentlige mål. Som skolegymnastik var den uegnet, hvorfor det øvelsesmæssigt var nødvendigt med en gennemgribende ændring af det bestående, hvis faget atter skulle blive alment tilgængeligt.

Undervisningsindholdet var dog ikke alene ondets rod. I 1884 udgjorde kravene til folkeskolens gymnastikundervisning 2-3 timer ugentlig enten i sal eller skolestue. Der var imidlertid stor forskel på, hvorledes kravene efterfulgtes i praksis, samt hvilke betingelser de udførtes under. I 1884 fandtes 2821 
offentlige folkeskoler med knapt 120.000 skolesøgende børn fordelt efter nedenstående skema.

\begin{tabular}{lcc}
\hline & antal skoler & antal børn \\
\hline København & 45 & 12.857 \\
Købstæder & 100 & 14.243 \\
Landsbyskoler & 2676 & 92.920 \\
\hline I alt & 2821 & 119.920 \\
\hline
\end{tabular}

Samme år forelå resultaterne fra en i 1882 nedsat skolehygiejnisk kommission, der skulle give en vurdering af skolebørnenes sundhedstilstand på landsplan. Kommissionen var nået frem til, at der generelt var stor sygelighed blandt børnene. Et resultat man satte i forbindelse med en manglende forståelse for legemlig opdragelse hos skoledirektionerne. Dette kom bl.a. frem ved at fokusere på fagets ydre rammer. I alle hovedstadens skoler fandtes en gymnastiksal. Det samme var tilfældet for 50 købstadsskoler. I landsbyskolerne var situationen imidlertid kaotisk. Kun 26 af de 2676 skoler havde gymnastiksal. Og endvidere blev det nævnt, at $7 \%$ ikke engang havde en legeplads. Dvs. i 1884 havde kun 121 folkeskoler med 20.000 børn acceptable faciliteter; hvorimod hele 2700 skoler med ca. 100.000 børn kun kunne tilbyde skolestuegymnastik eller sommerundervisning, når vejret tillod det.

Således var situationen i 1884. Men hvorledes var klimaet for noget nyt? Det synes som om flere parter var ved at få øjnene op for fagets trykkende tilstand. Amsinck havde som chef for det Militære Gymnastikinstitut erkendt den pædagogiske mangel i øvelsesindholdet; han var blot gået den forkerte vej. i sin løsningsmodel. Også skolemænd var begyndt at røre på sig, idet den skolehygiejniske kommission i 1882-84 havde bestået af personer, der alle havde kendskab til og dyb indsigt i skolens hverdag. Disse havde anbefalet mere gymnastikundervisning for begge køn og efterlyst en større forståelse for fagets betydning hos landets skoledirektioner. Dertil kom, at kommissionens forslag figurerede i kulturminister Jacob Scavenius' skolelovsforslag i 1885, der dog led skibbrud pga. de politiske tilstande. Der var således fra flere sider tale om en voksende forståelse for fagets betydning og mangelfulde tilstand. Men nogen koordineret indsats var der ikke tale om i denne lidt famlende fase. Det blev først aktuelt efter at højskolerne i 1884 fremviste en svensk gymnastikform og dermed opstillede et alternativ til det bestående. 


\section{I/ Gymnastikdebatten 1884-87}

I vinteren 1883/84 vendte N. H. Rasmussen hjem til Vallekilde højskole efter et 4 mdr's studieophold ved det Kgl. Gymnastiske Centralinstitut i Stockholm. Med dette kursus som ballast indledte han sin pionerindsats for udbredelsen af et rationelt gymnastiksystem, og dermed blev kimen lagt til skolegymnastikkens reformering.

Den svenske gymnastik var fortrinlig egnet som massegymnastik. Legemsøvelserne bestod af meget små og isolerede øvelsesenheder, som efter anatomiske og fysiologiske undersøgelser var sat sammen til fastlagte øvelsesprogrammer - dagsøvelser. Foretog man fx en kropsvridning til højre, skulle den modsvares af en tilsvarende bevægelse til venstre; bøjede man venstre arm, skulle den straks strækkes ud, hvorefter man foretog de samme bevægelser med højre arm. Denne enkelt- og alsidighed havde rod i sygegymnastikken og fandt sted i overensstemmelse med øvelsens virkning på kroppen. De systematiserede dagsøvelser sikrede, at hele legemet gradvist blev gennemarbejdet op til flere gange i hver time. Systemet havde umiddelbart 2 fordele. For det første blev der stillet så ringe krav til deltagernes forudsætninger, at alle - børn og voksne, piger og drenge - kunne være med. For det andet kunne læreren undervise op til 200 elever på én gang.

N. H. Rasmussens rationelle gymnastik var ikke helt så enkel, idet han krydrede den svenske systematik med redskaber som barre, trapez og springbrædt. Disse redskaber var alle lyst $i$ band af svenskerne, som fandt dem skadelige og tjenende akrobatikkens løsagtigheder. Men da Rasmussen fandt den rent svenske gymnastik for kedelig, gennemførte han de nævnte justeringer. Det var denne systematiserede blandingsgymnastik Vallekilde højskole lancerede i feb. 1884, og som samme år blev videreført til Askov Højskole.

For at bringe sagen videre udbredelse blev der i 1885 formidlet et 2 mdr's kursus for 12 danske gymnastiklærere hos Carl Norlander, en svensk gymnastiklærer i Lund (den såkaldte Norlandertylvt). Efter hjemkomsten blev den svenske gymnastik i vinteren 1885/86 indført på Mellerup, Testrup og Vejstrup højskoler. Samtidig startede en intensiv agitation for svensk gymnastik i Højskolebladets spalter, hvor de hyppigste argumenter var referencer til gymnastikkens nordiske ophav samt dens evne til at forme legemet ,,i den retning, hvorpå Skaberen havde tænkt ved dette sit allerskønneste værk“. Men ingen af indlæggene berørte skolegymnastikkens forhold. Det gjorde derimod N. H. Rasmussen i en artikel i tidsskriftet Vor Ungdom, hvor han lagde op til en diskussion af fagets indhold, idet han hævdede, at tiden nu var inde til en systematisk og rationel gymnastikundervisning. Og med Rasmussens bemærkninger som forløber blev emnet taget op til diskussion i foråret 1886. 
I feb. trådte lægen, og bestyrelsesmedlem i den dansk-orienterede Københavns Gymnastikforening, Chr. Fenger frem på podiet og gjorde sig til talsmand for en ændret skolegymnastik. Fenger understregede det uheldige i, at „,militærgymnastikken“ på bekostning af ,udviklingsgymnastikken“ var lagt til grund for fagets øvelsesindhold. Det Fenger var ude efter, var en rationel blandingsgymnastik, da han nærede frygt for, at en ren svensk gymnastik lagde for megen vægt på ensartet uddannelse. Iflg. hans mening kunne et sådant gymnastikindhold godt etableres, uden at de videnskabelige fordringer til anatomi og fysiologi blev krænket.

Når man tager i betragtning, at højskolerne selv praktiserede en systematiseret blandingsgymnastik, skulle man forvente, at dens talsmænd gik ind i en positiv dialog med Fenger. Men højst uventet afviste Norlandertylvtens deltagere forslaget i en række efterfølgende indlæg. Artiklernes røde tråd var ordet ,videnskabelighed“", idet højskolefolkene affærdigede tanken med en henvisning til, at det svenske gymnastiksystem var knyttet sammen af ,,indre organiske bånd", der ikke lod sig ændre uden tab af den videnskabelige basis. Samtidig blev de danske øvelser forkastet med en henvisning til, at landets gymnastikautoriteter var ,fuskere“, der ikke kendte mere til anatomi og fysiologi end almindelige mennesker.

Hvad var nu baggrunden for højskolernes paradoksale kovending? Blandt kildematerialet findes en hidtil ukendt brevsamling centreret omkring N. H. Rasmussen, der bl.a. kaster lys over Norlandertylvtens uddannelse i Lund. Iflg. disse breve mødte højskolefolkene frem med forestillingen om en systematisk blandingsgymnastik og forsøgte under opholdet at fastholde denne gymnastikform. Men de stred forgæves. Norlander afviste på det bestemteste tanken, idet han netop slog på videnskabeligheden bag en ren svensk gymnastikform. Alt andet blev karakteriseret som uforenelig med rationel gymnastik; som fuskeri. Og ved samtidig at give undervisningen et videnskabeligt tilsnit i form af dissektion og latinske navne, lykkedes det ham at overbevise danskerne om blandingsgymnastikkens utilstrækkelighed. Opholdet medførte således, at højskolefolkene efter hjemkomsten forkastede blandingsgymnastikken til fordel for en ny kurs, - den rene svenske gymnastik, der nærmest var at betragte som sygegymnastik. Med dette gymnastikskifte indledte højskolefolkene forårsdebatten med Fenger.

Højskolefolkenes optræden i foråret 1886 fik uheldige konsekvenser for en umiddelbar ændring af skolegymnastikkens forhold. Ved at kræve den svenske gymnastik indført med hud og hår og ved de iøjnefaldende udfald mod dansk gymnastik satte højskolefolkene sig selv $i$ en position, hvor modparten kun kunne opfatte dem som kompromisløse i deres krav. Det kunne de tillade sig over for en enkeltperson som Fenger. Men med den sønderlemmende kritik af dansk gymnastik og dens repræsentanter - mili- 
tærfolkene - var det i realiteten ikke længere et anliggende mellem højskolen og Fenger, men mellem Højskolen og Det militære Gymnastikinstitut. Instituttet kunne ikke undgå at se skriften på væggen, da højskolens talsmænd affærdigede Fengers forslag, der gik langt videre end de forandringer, Amsinck havde lagt op til i 1883. Og når det videnskabelige aspekt ligeledes blev betonet så stærkt i polemikken, må den svenske gymnastik for Gymnastikskolen have stået som en trussel for skolens eksistens. Hvilken funktion kunne skolen få udover uddannelsen af hærens egne gymnastiklærere? Eller hvorledes ville skolens gymnastiklærere blive fremstillet $\mathrm{i}$ fremtiden, når de ikke havde nok kendskab til anatomi og fysiologi, der efter højskolens opfattelse skulle være grundpillen i et nyt gymnastiksystem? Disse spørgsmål, som for det Militære Gymnastikinstitut var af central betydning, tog højskolen ikke stilling til, selv om de var forudsætningen for en ændret skolegymnastik. Hvis man så samtidig tager i betragtning, at højskolefolkene med undtagelse af Poul la Cour fra Askov Højskole fremførte sine synspunkter i det forsvarsvenlige organ, Vort Forsvar, fremstår deres fremtoning som provokerende. Herved fik debatten en ny og langt mere politisk dimension, idet det Militære Gymnastikinstitut var underlagt Krigsministeriet, der sammen med partiet Højre befandt sig $i$ et politisk slagsmål med Venstre omkring en ny forsvarsordning. Krigsministeriet havde derfor ingen fidus til sager, som var knyttet sammen med højskolebevægelsen. Det var den rationelle gymnastik, og så længe det var tilfældet, var der lange udsigter til skolegymnastikkens modernisering. I april 1886 opfordrede la Cour den svenske gymnastiks venner til at samle sig om det praktiske arbejde, da han fandt debatten formålsløs og skadelig. Og det blev signalet til, at højskolebevægelsen som gruppe trak sig ud af den officielle gymnastikdebat.

Under denne fase af udviklingen, hvor det så sortest ud for fagets fornyelse, overtog skolens egne repræsentanter kampen for en tidsvarende skolegymnastik. Men situationen var vanskelig. Dels fordi skolens minister, Scavenius, var højskolemodstander; han havde således frataget statsstøtten til disse skoler i 1885, dels fordi Scavenius stod på god fod med krigsminister J. Bahnsen. Hvis skolefolkene derfor ville gøre sig håb om at få faget gjort tidssvarende, var det tvingende nødvendigt, at de formåede at løsrive den svenske gymnastik fra højskolerne. Det måtte tage sig ud som om skolen, og ikke højskolen, ønskede et rationelt gymnastiksystem.

Blandt skolefolkene fandtes flere betydelige deltagere $\mathrm{i}$ datidens pædagogiske diskussioner, men primus motor i arbejdet var ministeriets nyudnævnte skolekonsulent, prof. Kristian Kroman. Kromans inddragelse skabte på flere måder en ændret situation. For det første syntes Scavenius, der havde sørget for Kromans udnævnelse, og Kroman at have et sammenfaldende syn på fagets store betydning, idet førstnævnte i skolelovsforslaget fra 1885 havde 
anbefalet faget et større timetal. Dernæst markerede skolekonsulentens deltagelse, at debatten havde nået de kredse, der var dens egentlige genstand. For det tredie kom Kromans arbejde til at betyde, at fagets forhold nu blev drøftet $i$ form af en helhedsbetragtning omhandlende såvel et nyt undervisningsindhold som en ændret gymnastiklæreruddannelse. Og endelig krævede skolefolkene, at Undervisningsministeriet alene skulle varetage fagets forhold. Det sidste betød, at det Militære Gymnastikinstitut ikke længere skulle uddanne gymnastiklærere til skolen, ligesom de heller ikke skulle have noget at gøre med undervisningsindholdet. Unægtelig en stor mundfuld.

Skolefolkenes strategi kan bedst karakteriseres som de lukkede døres politik, og deres inddragelse i sommeren 1886 foregik i al ubemærkethed. I hvert fald for offentligheden. De gik stille med dørene. Sagen skulle ikke drøftes af andre end folk med tilknytning til skolen. Og dette forhold skal sandsynligvis ses som baggrund for, at de på det tidspunkt ikke meddelte sig til offentligheden. Hvis de skrev, var der risiko for, at de ville blive sat i bås med højskolefolkene, hvorved skolefolkene kunne svække deres egen situation over for Scavenius. Når de derfor endelig trådte frem på arenaen, valgte de områder, der lå under Svavenius, hvorved de udadtil kunne vise deres uafhængighed af højskolebevægelsen. Det første offentlige fremstød blev sat ind i december 1886, da Kroman indbød til foredrag i Studenterforeningen, idet det efter hans opfattelse var af en vis betydning at vinde studenterne for sagen. Til dette foredrag havde skolefolkene inviteret nogle svenske studenter, der skulle illustrere et rationelt gymnastiksystem. Det næste offentlige fremstød fandt også sted i et forum for skolens forhold. Stedet var det Pædagogiske Selskab i København og var valgt med omhu, fordi foreningen havde et vist officielt anstrøg. ,Intet menneske vil mistænke den for agitation", som det lød i et af brevene fra de implicerede skolefolk.

For at nå de vidtrækkende mål, var skolefolkene sig bevidst, at hele spørgsmålet om fagets reformering skulle debatteres $i$ et mere snævert forum. Man forestillede sig nedsættelsen af en gymnastikkommission bestående af få personer, der skulle kulegrave fagets forhold. Dette kom på tale i efteråret 1886. Skolefolkenes problem var imidlertid at bevæge Scavenius til at bakke tanken op. Men ved hjælp af den gennemførte strategi fik de gevinst. Gymnastikkommissionen blev nedsat den 7. april 1887.

Hermed var gymnastikdebatten slut. Da den startede i 1884 var det både fra Amsincks, Scavenius' og forskellige skolefolks side erkendt, at faget stod i stampe og trængte til nye impulser. Men der var næppe nogen, der havde forestillet sig, at fagets forhold skulle gennemgå så radikale ændringer, som det nu så ud til. Når det overhovedet kunne komme på tale at indføre dels et 
rationelt gymnastiksystem dels en civil læreruddannelse, var det skolefolkenes fortjeneste. De havde ved deres indtræden i sommeren 1886 alle odds imod sig. Højskolen havde ved sin uhæmmede og forvrængede kritik af dansk gymnastik og dens bagmænd bragt sagen i baglås. Samtidig havde det Militære Gymnastikinstitut, dens ledelse og elever, en så lang tradition som skolegymnastikkens varetagere, at de ministerielle kredse vaklede mht. at stille institutionen uden for indflydelse. Men med en strategi der dels undgik berøring med alt, der kunne ligne agitation, dels skiftede klientel for diskussionen symboliseret ved den opsluttende kreds af skolefolk, samt foredrag i Studenterforeningen og Pædagogisk Selskab, lykkedes det skolens egne repræsentanter at løsive den rationelle gymnastik fra højskolen, så ministeren kunne se det fornuftige i nedsættelsen af en gymnastikkommission. Strategiens succesfulde udfald var sandsynligvis betinget af Kromans stilling som skolekonsulent, idet han førtes tæt på de egentlige beslutningstagere, ministeren og embedsmændene. Han havde derfor de rette betingelser for at kunne påvirke samt finde ud af ,,hvad der skulle til".

Gymnastikdebattens konsekvenser for skolegymnastikkens modernisering blev som det væsentligste, at ministeriet med gymnastikkommissionens nedsættelse havde givet principiel tilslutning til de omfattende forandringer på området. Kommissionen kom til at bestå af Amsinck, Kroman samt lægen Axel Hertel. Tidligere er denne sammensætning taget til udtryk for, at ministeriet ikke havde taget stilling til om det nye undervisningsindhold skulle være dansk eller svensk gymnastik. Amsinck blev som chef for det Militære Gymnastikinstitut tillagt dansk-orienterede synspunkter, det samme gjaldt Hertel, mens Kroman var fortaler for et rationelt system. Sammensætningen skal dog snarere ses $i$ et andet lys. Kroman var skolekonsulent; Hertel en anerkendt skolehygiejniker, der havde siddet $i$ den skolehygiejniske kommission 1882-84; og endelig forlod Amsinck pr. 1. jan. 1887 posten som chef for det Militære Gymnastikinstitut for at tiltræde stillingen som landets gymnastikinspektør med skolens forhold som ansvarsområde. Det væsentligste ved 1887-kommissionens sammensætning synes derfor at have været, at skolens minister sammen med skolens egne mænd nu koordinerede deres anstrengelser $i$ et forsøg på at komme fagets mangelfulde tilstand til livs.

Da kommissionen i 1888 afgav betænkning, var reformernes rammer slået fast. Undervisningsministeriet skulle være eneansvarlig for fagets fremtidige udvikling; der skulle oprettes en læreanstalt til uddannelse af skolens gymnastiklærere; undervisningsindholdet skulle dels bestå af rationel systematiseret blandingsgymnastik med såvel danske som svenske øvelser dels af boldspil og anden idræt. Efter disse retningslinjer nedsatte ministeriet i 1889 en ny gymnastikkommission, som fik til opgave at udforme en ny gymnastikhåndbog til skolens brug. 


\section{Reformerne gennemføres}

1889-kommissionens arbejde blev en langsommelig affære og først i 1899 kunne ministeriet udsende sin nye gymnastikhåndbog. På et fremskudt tidspunkt under kommissionens virke - i 1896 - blev ministeriet fra de pædagogiske kredse i København gjort opmærksom på boldspillenes betydning som et vigtigt pædagogisk middel til ungdommens legemlige opdragelse. Ministeriet var ikke ukendt med boldspillenes betydning, idet kommissionen på dette tidspunkt var færdig med den del af håndbogen, der omhandlede denne kategori af legemsøvelser. Det nye i situationen var imidlertid, at det Pædagogiske Selskab havde arbejdet for boldspillenes udbredelse gennem et par år. Det samme havde Legepladsforeningen i København, en tværpolitisk græsrodsbevægelse hovedsagelig bestående af lærere, hvis formål dels var at skaffe legepladser dels at udbrede kendskabet til boldspillenes betydning. Medlemslisten var ikke synderlig stor, men i kraft af en række indflydelsesrige personer havde den vægt bag sit arbejde. Det gjaldt bl.a. kultusminister Bardenfleth, folketingsmedlemmerne K. Berntsen og $\mathrm{H}$. Trier, nogle ministerielle embedsmænd samt medlemmerne af gymnastikkommissionen Hertel, Fenger og Kroman. Foreningen havde siden sin oprettelse i 1891 udført et praktisk stykke arbejde for hovedstadens unge ved $i$ børnenes fritid at stille lærere til rådighed som instruktører. Da ministeriet derfor i 1896/97 besluttede at indføre boldspil i skolens gymnastikundervisning, og i den anledning udsendte kommissionens færdige arbejde som særtryk, var handlingen et feed-back på en spirende interesse og praktiske iværksættelser fra hovedstadens pædagogiske kredse.

Den fuldstændige omlægning af skolegymnastikkens indhold blev en realitet med udsendelsen af håndbogen i 1899. Kommissionens medlemmer havde lavet et gymnastiksystem efter anatomiske og fysiologiske retningslinjer, men systemets øvelser var hentet fra nær og fjern; fra det militære gymnastikreglement, fra Sverige samt fra Tyskland. Det vil derfor være rigtigst at karakterisere systemet som en systematiseret blandingsgymnastik.

Derudover var håndbogen interessant ved, at den lagde op til en pædagogisk-faglig nyvurdering af gymnastik som skolefag. Dels var der med alsidigheden $\mathrm{i}$ øvelsesstoffet tale om en mere elevvenlig undervisning. Faget skulle ikke i lighed med tidligere opfattelse betragtes som et nødvendigt onde, men være en behagelig oplevelse. Og som noget nyt skulle også pigerne have gymnastik efter et mere regelmæssigt mønster. Dertil kom et hygiejnisk opdragende element $\mathrm{i}$ fagets nye image. I en tid hvor ungdommens legemlige tilstand lod meget tilbage at ønske, var det ikke uvæsentligt, at faget kunne bruges som formidler af hygiejnens sundhedsskabende effekt. Og med håndbogens plæderen for både badning samt svømning kunne dette aspekt glide ind som en naturlig del af elevernes hverdag. 
Undervisningsministeriet forsøgte således at lancere skolegymnastikken under en efter datidens forhold meget moderne indfaldsvinkel, der i realiteten betød, at fagets formål strakte sig ud over det rent færdighedsmæssige aspekt, som hidtil havde udgjort fagets primære funktion. Man forsøgte dermed at få faget integreret i skolepolitikken i en udstrækning, der ikke tidligere havde været praktiseret. Men samtidig krævede man en formidling af faget, som de eksisterende gymnastiklærere ikke havde uddannelse til, hvilket gjorde oprettelsen af en civil gymnastiklæreruddannelse påkrævet. Det var samtidig nødvendigt at oprette efteruddannelseskurser til de eksisterende lærere.

Uden at forklejne 1889-kommissionens arbejde og betydning i skolegymnastikkens samlede reformering, må det dog fastholdes, at det nye undervisningsindhold kun var en sekundær faktor for fagets reelle integrering $\mathrm{i}$ skolepolitikken. Den status, man ønskede, at skolegymnastikken skulle tilegne sig, var afhængig af fagets formidlere - gymnastiklærerne. Manden, der skulle føre tankerne ud i praksis, blev P. E. M. Ramsing - Amsincks efterfølger som gymnastikinspektør. Som nyudnævnt $i$ embedet må Ramsings stilling i 1899 have forekommet frustrerende. Skoleloven af 1899 havde gjort gymnastikken obligatorisk for pigerne i købstadsskolerne og påpegede det ønskelige i, at landsbyskolerne så vidt muligt fulgte dette spor. Samtidig stod landet med en meget forskelligartet lærergruppe. Folkeskolens lærere var uddannet på seminarierne, hvor underofficerer varetog fagets undervisning, skønt disse ikke var bekendt med skolens verden. Det samme var tilfældet på gymnasierne. Problemerne vedr. de sidstnævnte skoler løstes først endeligt med indførelsen af bifagsstudiet ved Kbh's universitet i 1913 et aspekt artiklen dog undlader at behandle. Folkeskolens forhold blev der derimod taget fat på med det samme.

Den umiddelbare forudsætning for udbredelsen af håndbogsgymnastikken var, at lærerne fik kendskab til fagets nye hensigter. Og hermed kom seminarierne i fokus. Den 15. maj 1900 udstedte ministeriet et cirkulære for disse, hvor det blev bekendtgjort, at man fra og med sommeren 1901 ville eksaminere efter håndbogen. Samtidig præciserede man fordelingen mellem undervisningen i gymnastik og boldspil, så hver kategori fik 2 ugentlige timer. Altså en ligelig fordeling helt i overensstemmelse med håndbogens tvedeling. I november blev dette cirkulære fulgt op af et nyt, som for første gang nogensinde indførtes en 2 timers skriftlig prøve i gymnastik. Stoffet, der skulle eksamineres i, gik på tværs af det samlede pensum, så eleverne skulle have kendskab til såvel de køns- og aldersmæssige forhold som til de anatomiske og fysiologiske grundsætninger. Hermed havde ministeriet stillet krav om en kvalitativ forbedring af de kommende gymnastiklæreres uddannelse. 
Men var der stillet større krav til de studerende, så medførte disse dog samtidig, at seminariets egne gymnastiklærere måtte dygtiggøre sig. De skulle selv være uddannet i den nye gymnastik inden sommeren 1901. Hertil bestod Ramsings uddannelsesapparat i 1900 af et et-årigt gymnastikkursus samt et feriekursus.

Det et-årige gymnastikkursus blev oprettet i 1898 under Statens Lærerkurser. Det var den første civile gymnastiklæreruddannelse her i landet siden 1816, hvor en tilsvarende uddannelse måtte lukke, og som følge deraf var uddannelsen ensbetydende med en stor prestige for Statens Lærerkurser som helhed. Der var tale om en hel uddannelse med undervisning i såvel gymnastik og boldspil som anatomi og fysiologi. Og kurset, der i 1911 blev en selvstændig institution, kom til at udgøre krumtappen i landets civile gymnastiklæreruddannelse frem til 1975, hvor også Odense Universitet fik en tilsvarende uddannelse. I 1940 fik institutionen sit nuværende navn Danmarks Højskole for Legemsøvelser.

I 1900 havde det Et-årige Kursus uddannet 55 civile gymnastiklærere; 3 af disse var seminarielærere. Men for at klarlægge om seminarierne som helhed var i stand til at formidle den nye gymnastik fra sommeren 1901, undersøgte jeg via nogle navnelister fra lærerkursernes årsberetninger, hvorvidt lærerne enten havde været på efteruddannelseskurser eller havde taget den et-årige uddannelse. Resultatet viste, at alle seminarier med undtagelse af 2 havde uddannede lærerkræfter til at eksaminere i håndbogsgymnastik fra sommeren 1901. 6 seminarielærere havde det et-årige kursus som ballast; 15 havde været på ferie-kursus. De 2 seminarier, som ikke kunne indfri kravene var statsseminarierne Jelling og Skaarup; året efter var sagen dog bragt i orden.

Konklusionen må derfor blive, at det under overgangsfasen lykkedes Ramsing og ministeriet at få seminariernes forhold tilpasset skolegymnastikkens nye fordringer. For det første var seminarielærerne - hvis vi ser bort fra skønhedsfejlene på Jelling og Skaarup - blevet omskolet, så afgangsklasserne fra og med 1901 formidlede håndbogsgymnastik. Dernæst gennemgik undervisningen en kvalitativ forbedring med indførelsen af den skriftlige eksamen. Hermed var den første forudsætning for den nye gymnastiks succesfulde udbredelse tilvejebragt. En anden vigtig faktor - forbedrede faciliteter - var på landsplan først tilendebragt langt op i dette århundrede, da alle landsbyskolerne fik gymnastiksale. Men mht. dette spørgsmål spillede de geografiske forhold en væsentlig rolle; således var forholdene stort set i orden i København og købstæderne allerede omkring århundredeskiftet. 


\section{Undersøgelsens resultater - hvad kan de bruges til?}

Med indførelsen af gymnastikhåndbogen i 1899 blev den danske skolegymnastik for første gang underlagt de moderne principper, der siden har dannet grundlaget for al fysisk uddannelse. Hermed gik statsinstitutionerne i spidsen for udbredelsen af legemsøvelser i overensstemmelse med naturvidenskabelige og pædagogiske kriterier. Man havde fået tilvejebragt et tidssvarende øvelsesforråd, som man samtidig blev i stand til at formidle i kraft af en forbedret gymnastiklæreruddannelse. Disse nyskabelser var projekteret af den første gymnastikkommission i 1887-88. Og i forlængelse heraf må man konkludere, at der ikke er belæg for antagelsen om, at skolegymnastikkens fornyelse og overgang fra militært til civilt regie havde rod i Venstres regeringsdannelse i 1901; heller ikke i Venstrekredsenes styrkelse op til systemskiftet. På det tidspunkt var moderniseringen stort set realiseret, idet man blot manglede en ordning for de universitetsstuderende. Den faldt på plads i årene 1907-13, hvor det Pædagogiske Selskab atter spillede en markant rolle. At planerne var så godt som gennemførte forud for systemskiftet underbygges ved, at der ikke umiddelbart fulgte noget nyt på området $\mathrm{i}$ 1901, men at den første nyskabelse efter Venstres tiltrædelse var oprettelsen af en fast lærestol i gymnastik ved seminarierne i 1903. Hvad angår de udsendte cirkulærer i 1900 har vi allerede konstateret, at seminariernes ,,begrænsede“ boldspilsundervisning blot var at betragte som en justering af forholdene efter håndbogens færdiggørelse. Den 4. dec. samme år udsendte ministeriet ligeledes et cirkulære til skolerne. Heller ikke her var der tale om en begrænsning af boldspillene, men udelukkende om en vejledning i benyttelse af håndbogens gymnastiksystem. Ministeriet forsøgte således ikke at forfordele den ene kategori på bekostning af den anden.

Når skolegymnastikkens modernisering ikke havde noget at gøre med systemskiftet i 1901, hang det sammen med, at højskolebevægelsen allerede i foråret 1886 gled ud af gymnastikdebatten og ikke siden fik nogen indflydelse på begivenhedsforløbet. Fagets modernisering skal derfor snarere ses i relation til det 19. århundredes generelle skoledebat. Som en understregning af dette synspunkt har opgaven vist, at reformbestræbelsernes bagvedliggende kræfter konstant var at finde inden for den danske skoleverden. Det gjaldt Kroman som skolekonsulent, Amsinck og Ramsing som gymnastikinspektører, Hertel som skolehygiejniker, flere markante skolefolk som fx Hans Olrik, Joakim Larsen, Emil Slohmann, Legepladsforeningen og endelig det Pædagogiske Selskab. En vifte af skolefolk, der vidner om en bred opbakning. Men hvor et debatemne som fx tankerne om en gymnasiereform var forbundet med så stor politisk prestige, at det først blev en realitet efter systemskiftet i 1901, var gymnastiksagen imidlertid underlagt så ringe en betydning i offentlighedens bevidsthed, at reformerne lod sig 
iværksætte efter det politiske forlig i 1894.

Det var opgavens resultater; og hvad kan idrætshistorien så bruge dem til???

Forhåbentlig til at danne nye forskningsopgaver. Ovenstående resultater har således givet mig anledning til at stille spørgsmål til højskole- og skyttebevægelsens placering i den danske gymnastiktradition.

Hidtil har det været antaget, at højskolegymnastikken var at betragte som en entydig størrelse - betegnet svensk gymnastik - samt at denne gymnastikforms folkelige tradition havde rod $\mathrm{i}$ redskabernes ringe betydning for øvelserne. Når man endelig benyttede sig af redskaber, gjaldt det universalredskaberne bom og ribbe, som kunne indstilles efter det enkelte menneske. Her viste undersøgelsen imidlertid, at højskolen i midten af 80'erne opererede med 2 varianter. Og endvidere at $\mathrm{N}$. H. Rasmussen/Vallekildegymnastikken, der forplantede sig til Askov Højskole, brugte redskaber klassificeret som specifikke varetegn for dansk gymnastik og dens elitære/akrobatiske uddannelsesmål. Det medfører, at det hidtil skarpt afgrænsede billede af højskolegymnastikkens egenartede gymnastikform nu har karakter af en mere udflydende skikkelse. Hvad dyrkede de i realiteten af gymnastik efter 1885? Var højskolen virkelig i stand til at gennemføre en ren svensk gymnastikform efter blot 2 mdr's kursus i Lund; eller blev den praktiserede gymnastik snarere en blanding af svensk og dansk efter en mere eller mindre hjemmestrikket model, alt efter den pågældende instruktørs egne kvalifikationer?

Højskolegymnastikkens gennemslagskraft på landet er et andet aspekt, der for mig står $\mathrm{i}$ et uklart lys. Det kan således synes paradoksalt at sammenholde betegnelsen ,,bondegymnastik" med landsbyskolernes ringe gymnastikforhold. Hvis den folkelige gymnastik var mest udbredt blandt landbefolkningen, hvorfor har det så ikke efterladt sig spor i landsbyskolernes faciliteter samt $\mathrm{i}$ de generelle gymnastikforhold? Dette kunne undersøges ved at se, om de landsbyskoler, der havde egen sal, lå i nærheden af højskoler eller markante skytteforeninger.

Disse 2 punkter stiller spørgsmål til højskolens placering inden for den danske gymnastiktradition, fordi vi ikke kender højskolens nøjagtige gennemslagskraft. Vi ved, at højskolefolkene meget tidligt gled ud af debatten om landets skolegymnastik. Og vi ved, at det lykkedes skolefolkene at få de moderne principper indført i skolegymnastikken. Herfra blev principperne siden bragt videre til den frivillige gymnastik. Således anmodede Indenrigsministeriet i 1896 på højskole- og skyttebevægelsens foranledning om, at Undervisningsministeriet ville trykke gymnastikhåndbogen af $1899 \mathrm{i}$ et forøget oplag på 7000 expl., hvoraf de 2000 bøger skulle bruges til den frivillige gymnastik. Spørgsmålet er derfor, om det i realiteten ikke var skolegymna- 
stikken, der var den afgørende faktor for udbredelsen af de moderne principper på landsplan. Hvorimod højskolerne først for alvor kom til at præge landets gymnastiktradition fra 1920, da Niels Buck startede Ollerup gymnastikhøjskole.

Skal man derfor nå en yderligere bestemmelse af, hvad højskolerne foretog sig i perioden 1885-1920, synes det nødvendigt med en analyse, der ikke tager udgangspunkt i de skriftlige agitationsartikler fra Højskolebladet og Vort Forsvar; som hidtil har været benyttet som det væsentligste kildemateriale. Men i stedet trænge dybere ned i de faktiske forhold, hvilket kun lader sig praktisere ved inddragelse af akter og arkivalier som $\mathrm{fx}$ højskolernes programmer, deres gymnastiklister, redskabstegninger m.m. Og forhåbentlig vil den eller de, der undersøger disse forhold, nå nogle resultater, som igen rejser nye spørgsmål. Måske til skolegymnastikkens udvikling 1884-1913. Måske til et andet felt. Det er ligemeget. Det idrætshistorien har brug for i sin afdækningsfase er resultater, der skaber kædereaktioner; ellers kommer myterne til at danne andre myter. 


\section{Fra Boksekampen mellem Jim Smith og Bobby Dobbs igaar.}

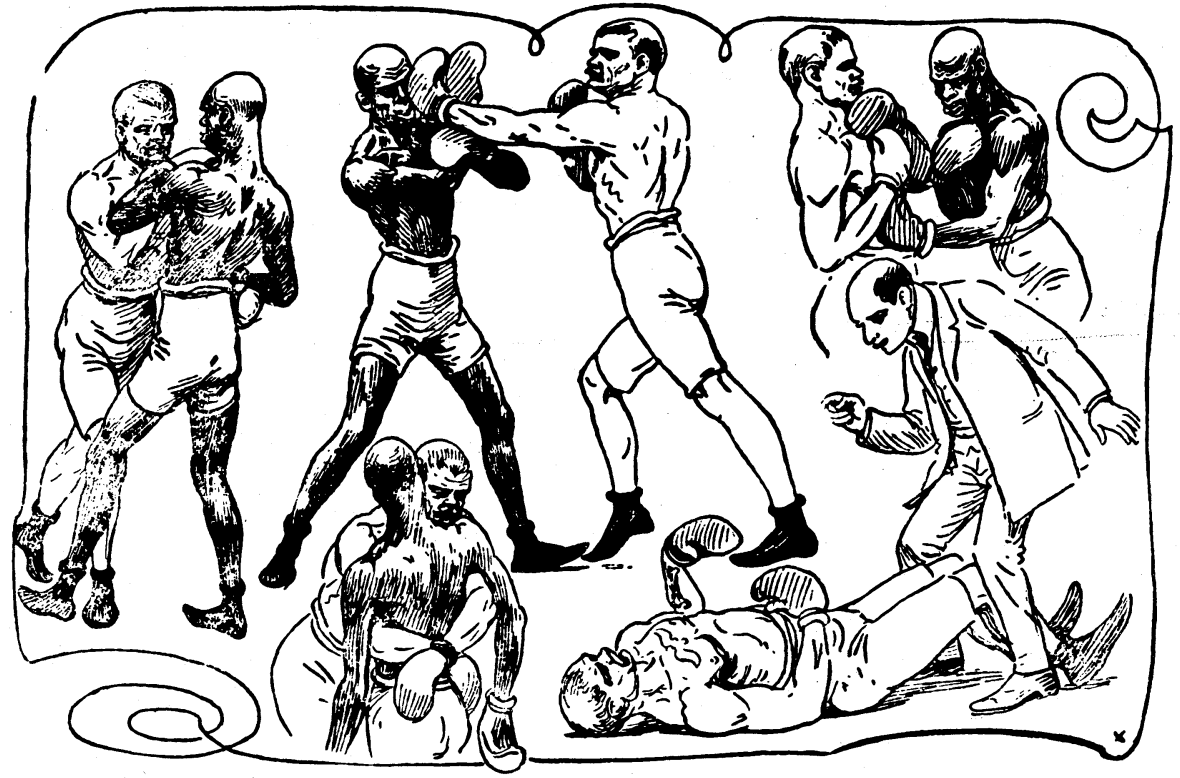

Fpisoder fra Kampen.

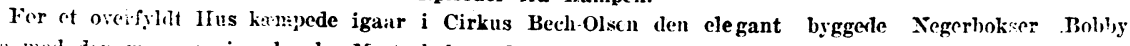
Dobbs not den mangianrige danske Mesterbokser Jim Smith.

Den 9. oktober 1910 var det den danske mesterbokser Jim Smiths tur til at møde amerikaneren Bobby Dobbs. Dobbs vandt på teknisk knock-out efter 11. omgang.

Jim Smith (1866-1911) hed egentlig Johannes Jørgensen, men antog sit engelske navn efter en rømning i Australien. I 1896 vandt han i den første professionelle kamp herhjemme over sprøjtefører $P$. L. Jacobsen. Jim Smith var også aktiv $i$ forbindelse med amatørboksningen, idet han var stifter af bokseklubben „Olympia“.

Cirkus Bech-Olsen, hvor kampen fandt sted, blev i øvrigt ejet af den navnkundige, tidligere professionelle bryder af samme navn. 